\title{
Ocular gene transfer in the spotlight: implications of newspaper content for clinical communications
}

\author{
Shelly Benjaminy and Tania Bubela*
}

\begin{abstract}
Background: Ocular gene transfer clinical trials are raising hopes for blindness treatments and attracting media attention. News media provide an accessible health information source for patients and the public, but are often criticized for overemphasizing benefits and underplaying risks of novel biomedical interventions. Overly optimistic portrayals of unproven interventions may influence public and patient expectations; the latter may cause patients to downplay risks and over-emphasize benefits, with implications for informed consent for clinical trials. We analyze the news media communications landscape about ocular gene transfer and make recommendations for improving communications between clinicians and potential trial participants in light of media coverage.

Methods: We analyzed leading newspaper articles about ocular gene transfer (1990-2012) from United States $(n=55)$, Canada ( $n=26)$, and United Kingdom ( $n=77$ ) from Factiva and Canadian Newsstand databases using pre-defined coding categories. We evaluated the content of newspaper articles about ocular gene transfer for hereditary retinopathies, exploring representations of framing techniques, research design, risks/benefits, and translational timelines.

Results: The dominant frame in $61 \%$ of stories was a celebration of progress, followed by human-interest in $30 \%$ of stories. Missing from the positive frames were explanations of research design; articles conflated clinical research with treatment. Conflicts-of-interest and funding sources were similarly omitted. Attention was directed to the benefits of gene transfer, while risks were only reported in $43 \%$ of articles. A range of visual outcomes was described from slowing vision loss to cure, but the latter was the most frequently represented even though it is clinically infeasible. Despite the prominence of visual benefit portrayals, $87 \%$ of the articles failed to provide timelines for the commencement of clinical trials or for clinical implementation.
\end{abstract}

Conclusions: Our analysis confirms that despite many initiatives to improve media communications about experimental biotechnologies, media coverage remains overly optimistic and omits important information. In light of these findings, our recommendations focus on the need for clinicians account for media coverage in their communications with patients, especially in the context of clinical trial enrolment. The development of evidence-based communication strategies will facilitate informed consent and promote the ethical translation of this biotechnology.

Keywords: Gene transfer, Gene therapy, Media, Newspaper coverage, Therapeutic misconception, Ethics, Informed consent

\section{Background}

The field of gene transfer, colloquially known as 'gene therapy', has followed a trajectory of high hopes and high profile failures. Historical abuses, including nondisclosure of serious adverse events and highly publicized conflicts-of-interest, have damaged its reputation [1-3],

\footnotetext{
* Correspondence: tbubela@ualberta.ca

Department of Public Health Sciences, School of Public Health, Edmonton
Clinic Health Academy, University of Alberta, 1140587 Ave NW, Edmonton,

Department of Public Health Sciences, School of Public Health, Edmonton
Clinic Health Academy, University of Alberta, 1140587 Ave NW, Edmonton, Alberta, Canada
}

(c) 2014 Benjaminy and Bubela; licensee BioMed Central Ltd. This is an Open Access article distributed under the terms of the

eroded public trust, and presented significant setbacks for its clinical development $[4,5]$.

Ocular applications may yet rescue the reputation of gene transfer with successful clinical trials beginning in 2007. Phase I clinical trials for Leber congenital amaurosis (LCA), a rare, blinding retinopathy, established both indexes of safety and improved visual function, despite the small size and safety focus of first-in-human phase I clinical trials [6-8]. Phase I trials are followed by larger phase II trials that continue to test safety and establish 
preliminary measures of efficacy. Phase III trials, most commonly randomized, controlled trials, are then statistically powered to test efficacy for primary (e.g., visual acuity) and secondary (e.g., retinal imaging) outcome measures. Sustained safety results for LCA [9] have led to a phase III clinical trial at the University of Pennsylvania, which is currently recruiting children (clinicaltrials.gov: NCT00999609). Developments in LCA trials have served as an impetus for further clinical trials for related ocular diseases [10], including Stargardt disease (clinicaltrials. gov: NCT01367444), retinitis pigmentosa (clinicaltrials. gov: NCT01482195), Usher syndrome (clinicaltrials.gov: NCT01505062), and choroideremia (clinicaltrials.gov: NCT01461213).

These recent advances in ocular gene transfer have triggered media attention [11], raising patient hopes [12] for the mediation of previously untreatable genetic diseases. News media are the most accessible source of information on biomedical research for the public and patients [13]. Media coverage, therefore, if exaggerated or misrepresentative of gene transfer, may influence societal and patient expectations.

News media are often blamed for distorting the impact of biotechnology research through overly aversive or favorable communications $[13,14]$. Media use frames (simplified, interpretive representations of an issue) to highlight the importance of an issue and how it should be addressed [15]. Frames often bias contentious scientific issues by placing greater emphasis on certain considerations while omitting others [16]. For example human embryonic stem cell research may be framed as ethically unjustifiable for its destruction of embryos or as an ethical imperative to provide cures for otherwise incurable diseases $[17,18]$. Biomedical reporting is often criticized for its framing that uncritically celebrates progress in research [19]. Such framing emphasizes benefits over risks [20], and omits crucial information such as funding sources and potential conflicts-of-interest [21,22]. The coverage often presents pre-clinical research (i.e., in-vitro or animal studies) as an imminent therapy or cure [20].

From a clinical perspective, the uncritical progress frame may lead clinicians, patients, and their families to form high expectations, only to be disappointed when reality falls short of hope, causing disillusionment among clinicians and despair among patient communities [23]. In the context of clinical trials, overly positive media coverage about research in progress may present challenges to enrolment and informed consent in ongoing or subsequent clinical trials by heightening patient expectations for therapeutic benefits [24]. In particular, potential participants may misunderstand the safety focus of early-phase trials and expect therapeutic outcomes [25].

As ocular gene transfer clinical trials for hereditary retinopathies increase in number and reach phase III, attention must be directed at facilitating ethical communications of risks and potential benefits for recruitment of clinical trial participants. Such communications will occur in an environment of heightened media coverage, with media influencing patient and public perspectives about pre-clinical and clinical gene transfer research. Here, we ask how newspaper articles report on ocular gene transfer for hereditary retinopathies, exploring errors of omission and biases in representations of framing, risks and benefits, as well as therapeutic potential. Our analysis suggests the need for clinicians to account for media coverage in their communications with patients, especially in the context of clinical trial enrolment. Evidence-informed communication strategies set against the media landscape will ensure the ethical translation of this biotechnology as it moves forward to clinical application.

\section{Methods}

We examined newspaper communication about ocular gene transfer between January 1, 1990 and June 30, 2012 in the top 50 United States (US), Canadian, and United Kingdom (UK) newspapers by circulation [26]. We selected 1990 as our start year because it corresponds to the first approved gene transfer clinical trial. These countries ranked within the top ten for production of gene transfer trials [27]; ocular gene transfer trials have commenced in the US and UK and will shortly commence in Canada. We used search algorithms for 'ocular gene transfer' in media databases Factiva and Canadian Newsstand. The initial search produced 2070 articles (84 Canadian, 647 UK, and 1339 US). After reading each article, we excluded all but original articles about gene transfer targeting retinopathies, resulting in 158 articles (26 Canadian, 55 US, and 77 UK) for analysis (Table 1).

We used pre-determined coding categories for our content analysis. The coding categories were modified from pre-existing studies about media coverage of health research and biotechnologies $[28,29]$ and adapted to include issues raised in similar studies [30-32]. Furthermore, the coding categories were developed in response to issues raised by forty-one semi-structured interviews with stakeholders of a phase I ocular gene transfer clinical trial (choroideremia patients, clinicians, and patient advocates). A thematic analysis of these interviews revealed high therapeutic hopes, limited attention to risks, and confusion about the timelines for the clinical application of gene transfer among patients [33]. The final coding categories investigated the attention structure of newspaper articles (word count, page number, news format), disease representations, key categories of spokespeople, one dominant frame for each article, use of human-interest stories, tone of coverage, description of methods, representations of timelines for translational research and clinical implementation, and representations of risks/benefits. Tone 
Table 1 Search algorithms for ocular gene transfer newspaper articles in Factiva and Canadian Newsstand

\begin{tabular}{llcc}
\hline Country & Search strategy & Number of articles & $\begin{array}{c}\text { Number of articles on } \\
\text { retinopathies for analysis }\end{array}$ \\
\hline United States & At least one of these words: blind* ocular ophtha* vision sight retin* eye & 1339 & 55 \\
& This exact phrase: gene therapy & & 26 \\
Canada & TITLE (blind* OR ocular OR ophtha* OR vision OR sight OR retin* OR eye) & 647 & 77 \\
& AND (gene therap*) & & \\
United Kingdom & At least one of these words: blind* ocular ophtha* vision sight retin* eye & 84 & \\
& This exact phrase: gene therapy & & \\
\end{tabular}

${ }^{\mathrm{a} A}$ truncation symbol $\left({ }^{*}\right)$ was used to capture alternative word endings of search terms (e.g. retin* captures retina, retinas, retinopathy, retinopathies, etc.).

of coverage was determined using a combination of quantitative (number of benefits stated versus number of risks) and qualitative (prominence and stated magnitude of benefits versus risks) assessments. If the article stated more benefits than risks, its tone was positive. However, where benefits and risks were equal in number, we considered their respective magnitude. For example, a benefit of "cure for blindness" versus the economic risk of "expense of the clinical trial" also indicated a positive tone.

A research assistant coded all articles, and one of the authors [SB] independently coded $19 \%$ to verify that a second coder would arrive at the same conclusion as the main coder. We calculated Cohen's Kappa for inter-coder reliability (SPSS 18: IBM). Kappa scores ranged between 0.71-1.0, displaying acceptable inter-coder agreement [34]. To accommodate the small sample size of Canadian newspaper articles, we used Fischer's chi squared tests (STATA 11: StataCorp 2009) to assess differences in coverage between countries. We used a Kruskal-Wallis Analysis of Variance (STATA 11: StataCorp 2009)-a non-parametric alternative to a one-way analysis of variance-to assess differences in the median number of benefit and risk representations between countries. We combined articles from the three countries when there was no significant difference in coverage $(\alpha=0.05)$.

\section{Results}

Most articles were published in the main news section with only $1 \%$ of articles appearing as front-page news. The average article word length was 615 words. Ninety two percent of articles were formatted as "latest news", and a minority was formatted as interviews (3\%), commentaries (3\%), and editorials (2\%). The articles covered a variety of retinopathies; some currently under the investigation of clinical trials and some that have not advanced beyond pre-clinical studies (Table 2). The distribution of newspaper articles over time is displayed in Figure 1.

\section{Dominant spokespeople and frames}

The most frequently quoted spokespeople were researchers from universities, research institutes or government; followed by patient advocacy organization representatives and affected individuals and their families (Table 3). The majority of Canadian and UK articles quoted a researcher compared to $38 \%$ of US articles (Table 3 ). Industry quotes were scarce in all countries with only a single article interviewing a private sector scientist and a second representing the views of a biotechnology company spokesperson. Largely missing were experts on legal or ethical issues.

The dominant frame in $61 \%$ of all stories was a celebration of progress in research with no significant difference in framing across countries. For example, a patient advocate was quoted as saying: "It's really nothing short of miraculous, .... You're talking about being able to restore vision in animals that are, essentially, totally blind. This is kind of the first fruit of the revolution in genetic medicine." [35]. Forty-seven of total articles (30\%) were dominantly framed as human-interest stories, and 68\% of these depicted the challenges of affected individuals living with genetic retinopathies. Forty percent of humaninterest stories portrayed affected patients as heroic or hopeful, while only one article conveyed the challenges of affected individuals through a lens of fatalism, depicting sorrow and hopelessness. The challenges of family members of affected individuals were described in $17 \%$ of the human-interest stories, and narratives of heroism and hope were present in 19\%. While researchers were frequently quoted in articles, only $4 \%$ presented humaninterest stories on gene transfer researchers, portraying them as heroes. The remainder of the articles (8\%) was presented using a descriptive frame, and displayed a neutral account of the science [16]. Other common frames in science journalism-such as conflict (the dominant frame in coverage of politically charged science topics such as climate change and evolution), economic development, morality, scientific uncertainty, risk, and public accountability [32]—were absent.

\section{Research design explanations}

Explanations of research design lacked detail and context in all countries (Table 4). Most striking was the subtle conflation of research and treatment, for example, "[t]o hear such quick progress in a gene therapy treatment is fantastic. We hope this success will lead to more funding of gene therapy research into conditions that currently have no cure or treatment" [emphasis added] [36]. 
Table 2 Retinopathies represented in newspaper articles compared to phase of clinical trials registered in clinicaltrials.gov

\begin{tabular}{|c|c|c|c|c|c|c|}
\hline $\begin{array}{l}\text { Disease }^{b} \\
\text { (number of articles }^{a} \text { ) }\end{array}$ & Nature of retinopathy & $\begin{array}{l}\text { Clinical trial } \\
\text { number }\end{array}$ & $\begin{array}{l}\text { Clinical } \\
\text { trial phase }\end{array}$ & Gene targeted & Vector type & $\begin{array}{l}\text { Number }(\mathrm{n}) \text { and } \\
\text { age of participants }\end{array}$ \\
\hline \multirow[t]{8}{*}{$\begin{array}{l}\text { Leber congential } \\
\text { amaurosis (84) }\end{array}$} & \multirow[t]{8}{*}{$\begin{array}{l}\text { Progressive retinopathy with severe } \\
\text { visual problems beginning in infancy. }\end{array}$} & NCT00999609 & III & RPE65 & $\begin{array}{l}\text { Adeno-associated viral vector; } \\
\text { AAV2-hRPE65V2 }\end{array}$ & $n=24 ; 3$ years and older \\
\hline & & NCT00749957 & $|/| \mid$ & RPE65 & $\begin{array}{l}\text { Recombinant adeno-associated } \\
\text { viral vector; rAAV2-CB-hRPE65 }\end{array}$ & $\mathrm{n}=12 ; 6$ years and older \\
\hline & & NCT01208389 & $|/| \mid$ & RPE65 & $\begin{array}{l}\text { Adeno-associated viral vector; } \\
\text { AAV2-hRPE65V2 }\end{array}$ & $\mathrm{n}=12 ; 8$ years and older \\
\hline & & NCT00643747 & $|/| \mid$ & RPE65 & $\begin{array}{l}\text { Recombinant adeno-associated viral } \\
\text { vector; rAAV 2/2.hRPE65p.hRPE65 }\end{array}$ & $n=12 ; 5-30$ years old \\
\hline & & NCT01496040 & $|/| \mid$ & RPE65 & $\begin{array}{l}\text { Recombinant adeno-associated } \\
\text { viral vector; rAAV-2/4.hRPE65 }\end{array}$ & $\mathrm{n}=9 ; 6-50$ years old \\
\hline & & NCT00481546 & । & RPE65 & $\begin{array}{l}\text { Recombinant adeno-associated } \\
\text { viral vector; rAAV2-CBSB-hRPE65 }\end{array}$ & $\mathrm{n}=15 ; 8$ years and older \\
\hline & & NCT00821340 & । & RPE65 & $\begin{array}{l}\text { Recombinant adeno-associated } \\
\text { viral vector; rAAV2-hRPE65 }\end{array}$ & $\mathrm{n}=10 ; 8$ years and older \\
\hline & & NCT00516477 & । & RPE65 & $\begin{array}{l}\text { Adeno-associated viral vector; } \\
\text { AAV2-hRPE65V2 }\end{array}$ & $\mathrm{n}=12 ; 8$ years and older \\
\hline Retinitis pigmentosa (37) & $\begin{array}{l}\text { Progressive retinopathy characterized } \\
\text { by gradual peripheral vision loss }\end{array}$ & NCT01482195 & । & MERTK & $\begin{array}{l}\text { Recombinant adeno-associated viral } \\
\text { vector; rAAV2-VMD2-hMERTK }\end{array}$ & $\mathrm{n}=6 ; 14-70$ years old \\
\hline \multirow[t]{2}{*}{$\begin{array}{l}\text { Age-related macular } \\
\text { degeneration (24) }\end{array}$} & \multirow[t]{2}{*}{$\begin{array}{l}\text { Progressive central vision loss usually } \\
\text { occurring in older adults }\end{array}$} & NCT01301443 & I & $\begin{array}{l}\text { Genes that encode } \\
\text { endostatin and angiostatin }\end{array}$ & Lentiviral vector; RetinoStat & $\mathrm{n}=18 ; 50$ years and older \\
\hline & & NCT01678872 & 1 & $\begin{array}{l}\text { Genes that encode } \\
\text { endostatin and angiostatin }\end{array}$ & Lentiviral vector; RetinoStat & $\mathrm{n}=18 ; 50$ years and older \\
\hline Choroideremia (7) & $\begin{array}{l}\text { Progressive retinopathy characterized } \\
\text { by gradual peripheral vision loss }\end{array}$ & NCT01461213 & $|/| \mid$ & REP1 & $\begin{array}{l}\text { Adeno-associated viral vector; } \\
\text { AAV.REP1 }\end{array}$ & $\mathrm{n}=12 ; 18$ years and older \\
\hline $\begin{array}{l}\text { Stargardt macular } \\
\text { degeneration ( } 7 \text { ) }\end{array}$ & $\begin{array}{l}\text { Progressive degeneration of the } \\
\text { macula causing central vision } \\
\text { loss beginning in childhood }\end{array}$ & NCT01367444 & I/lla & ABCA4 & Lentiviral vector; StarGen & $\mathrm{n}=28 ; 18$ years and older \\
\hline Usher syndrome (7) & $\begin{array}{l}\text { Progressive retinopathy (retinitis } \\
\text { pigmentosa) combined with hearing loss }\end{array}$ & NCT01505062 & l/lla & MYO7A & Lentiviral vector; UshStat & $\mathrm{n}=18 ; 18$ years and older \\
\hline
\end{tabular}

${ }^{\mathrm{a} S o m e}$ articles targeted more than a single retinopathy.

${ }^{b}$ Note that 18 articles referred to gene transfer targeting color blindness, one referred to retinocshisis, and one referred to congenital stationary night blindness, even though no clinical trials for these conditions were registered in clinicaltrials.gov. 


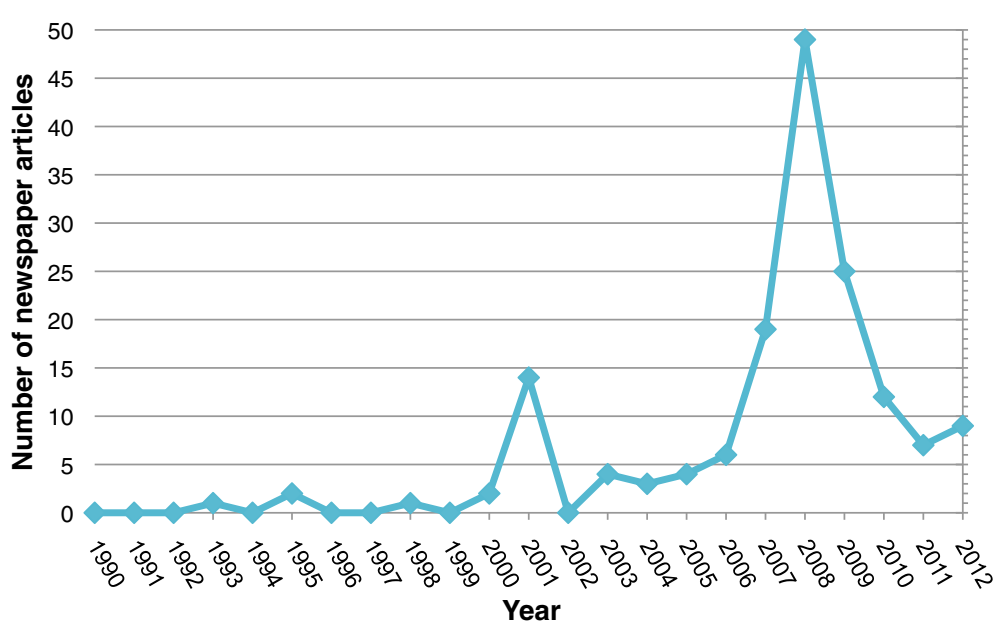

Figure 1 Distribution of newspaper articles about ocular gene transfer over time.

Sixty five percent of articles did not discuss sample sizes in research, and $87 \%$ of articles failed to indicate the phases of clinical trials. Canadian articles were more likely to discuss pre-clinical studies (i.e., in vitro or animal studies), while a greater proportion of UK and US articles discussed clinical trials (Table 4). UK articles were half as likely $(48 \%)$ to state that a gene mutation caused the genetic retinopathy under investigation, compared to Canadian (77\%) and US (71\%) articles. However, US articles were least accurate in their reporting of the function of gene transfer and the mechanics of its delivery (Table 4). Funding sources were mentioned in only $39 \%$ of all articles. Only $3 \%$ of articles described controversies and conflicts-of-interest. For example, controversy over the benefits of gene transfer for patients, who had adjusted to their visual impairment was described: "[w]hile the prospect of a cure is exciting, it can also be scary for people living with limited or no sight .... If they said, 'there's a cure and you're going to be able to see', they wouldn't just jump and say, 'Yes!' Because the whole world would change on them, ... They've both been able to carry on with their lives without sight. Then all of a sudden if you could see it wouldn't make sense ... They wouldn't be able to read" [37].

\section{Representations of risks, benefits, and timelines}

The tone of newspaper coverage was overwhelmingly positive in all countries (Figure 2). Benefits were disproportionately represented with a median of three benefits compared to a median of 0 risks (only $43 \%$ of articles described any risk) (Table 5). While some statistical differences existed among countries in reporting of risks, these are due to the very low percentages of articles that discussed specific risks (Table 5). The commonality among countries was the lack of reporting of risks. In general, no risks were mentioned in 35\% of Canadian, $69 \%$ of UK, and $53 \%$ of US articles. In contrast, all articles discussed benefits; visual improvement was prominently represented in Canadian (100\%), UK (91\%), and US (87\%) articles. Representations of visual benefit ranged along a

Table 3 Categories of spokespeople quoted in Canadian, United Kingdom, and United States newspapers

\begin{tabular}{|c|c|c|c|c|}
\hline \multirow[t]{2}{*}{ Spokesperson $^{a}$} & \multicolumn{3}{|c|}{ Percent (\%) of articles } & \multirow[t]{2}{*}{$P$-value } \\
\hline & Canada $(n=26)$ & United Kingdom $(n=77)$ & United States $(n=55)$ & \\
\hline $\begin{array}{l}\text { Researchers from universities/research } \\
\text { institutes/government }\end{array}$ & 85 & 57 & 38 & $0.000^{*}$ \\
\hline Patient advocacy organizations & 27 & 10 & 31 & $0.032^{*}$ \\
\hline Affected individuals & 19 & 27 & 33 & 0.359 \\
\hline Family of affected individuals & 19 & 11 & 22 & 0.259 \\
\hline Friends of affected individuals & 4 & 4 & 4 & 1.000 \\
\hline Ethics committees & 4 & 1 & 0 & 0.430 \\
\hline Parliament/Congress & 4 & 5 & 0 & 0.195 \\
\hline Media/Columnist opinion & 8 & 16 & 29 & $0.041^{*}$ \\
\hline
\end{tabular}

${ }^{a}$ Categories are not mutually exclusive, therefore add to $>100 \%$.

${ }^{\mathrm{b}}$ Statistically significant differences $(\mathrm{p}<0.05)$ are indicated by *. 
Table 4 Research design explanations in Canadian, United Kingdom, and United States newspapers

\begin{tabular}{|c|c|c|c|c|}
\hline \multirow[t]{2}{*}{ Research design explanations } & \multicolumn{3}{|c|}{ Percent (\%) of articles } & \multirow[t]{2}{*}{$P$-value } \\
\hline & $\begin{array}{l}\text { Canada } \\
(\mathrm{n}=26)\end{array}$ & $\begin{array}{l}\text { United Kingdom } \\
(n=77)\end{array}$ & $\begin{array}{l}\text { United States } \\
(n=55)\end{array}$ & \\
\hline Gene transfer is research & & & & 0.069 \\
\hline Clearly mentioned & 23 & 39 & 47 & \\
\hline Mentioned, but research/treatment conflation & 77 & 51 & 45 & \\
\hline Sample sizes stated & 42 & 29 & 40 & 0.274 \\
\hline Phase of clinical trial & & & & $0.000^{*}$ \\
\hline Mentioned & 4 & 3 & 5 & \\
\hline Not applicable & 27 & 0 & 0 & \\
\hline Gene mutation causes genetic retinopathies & 77 & 48 & 71 & $0.006^{*}$ \\
\hline Working copy of mutated gene is transferred to ameliorate disease phenotype & & & & $0.000^{*}$ \\
\hline Mentioned with accuracy & 58 & 53 & 21 & \\
\hline Mentioned, but incorrect/misleading terminology (e.g. Gene replacement) & 15 & 3 & 18 & \\
\hline Viral vector transports the gene of interest & & & & 0.078 \\
\hline Explained accurately & 35 & 23 & 18 & \\
\hline Explained, but viral modification not mentioned & 23 & 8 & 13 & \\
\hline Working gene is transferred to the back of the eye & 65 & 61 & 38 & $0.015^{*}$ \\
\hline Gene transfer involves eye surgery & 62 & 56 & 38 & 0.063 \\
\hline
\end{tabular}

${ }^{a}$ Statistically significant differences $(p<0.05)$ are indicated by *

continuum of outcomes (Figure 3) from slowing vision loss to a cure. For example, one article claimed, "REVOLUTIONARY gene therapy can cure a severe form of inherited blindness in days, groundbreaking trials show" [38]. Indeed, the more therapeutic the outcome along the continuum, the more frequently it was represented in newspaper articles (Figure 3); slowing down vision loss was rarely discussed compared to complete cure. No article indicated that deriving visual benefit from ocular gene transfer might be unlikely.

While the majority of articles predicted visual benefit as an outcome of ocular gene transfer, $87 \%$ of all articles did not provide estimates of timelines for the commencement of clinical trials, the phases of clinical trials,

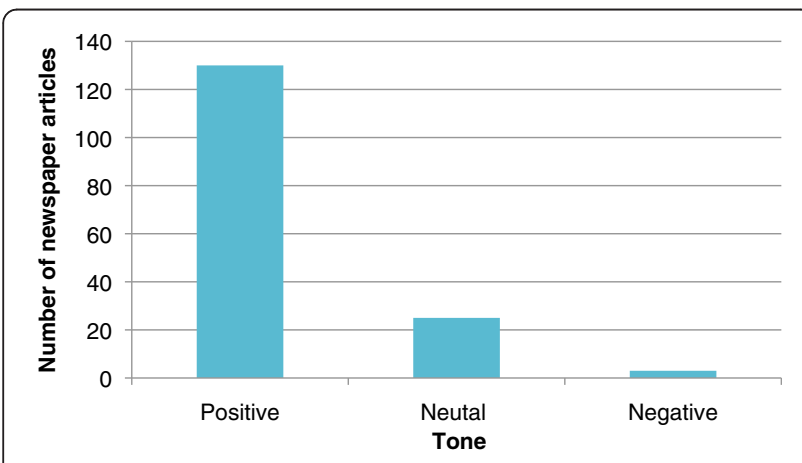

Figure 2 Tone of ocular gene transfer in newspaper articles from Canada, United Kingdom and United States. the regulatory process, or the clinical implementation of this biotechnology. Table 6 provides examples of statements that predict timelines for the translation of gene transfer research.

\section{Discussion}

Our analysis of newspaper coverage of ocular gene transfer identifies persistent challenges posed by overly positive representations of experimental biotechnologies in all three countries analysed. Sensationalism in the news media is seldom present as blatantly inaccurate reporting [20,28,31]. Instead, as for ocular gene transfer, overly enthusiastic or exaggerated claims are evident through biased framing, errors of omission, and an emphasis on benefits over risks. Such overly optimistic reporting serves to discredit media claims [39] and build heightened social expectations about the promise of emerging biotechnologies [40]. As such, the research community, policy makers, and ethicists view a lack of balance in media reporting as a major shortcoming [20].

Our analysis of newspaper coverage of ocular gene transfer identified minor differences in coverage in Canadian, UK and US print media, but the same essential concerns persisted. Coverage in all three countries focused on human-interest stories, dominant framing as a "celebration of progress", and had limited discussion of risks, research design, conflicts-of-interest, funding sources, and research timelines. US news articles were least likely to discuss the 
Table 5 Ocular gene transfer risks and challenges in Canadian, United Kingdom, and United States newspapers

\begin{tabular}{|c|c|c|c|c|}
\hline \multirow[t]{2}{*}{ Gene transfer risks, challenges, or caveats } & \multicolumn{3}{|c|}{ Percent (\%) of articles } & \multirow[t]{2}{*}{$P$-value ${ }^{\mathrm{a}}$} \\
\hline & Canada $(n=26)$ & United Kingdom $(n=77)$ & United States $(n=55)$ & \\
\hline Not mentioned & 35 & 69 & 53 & $0.006^{*}$ \\
\hline General health risk & 19 & 17 & 33 & 0.098 \\
\hline Efficacy concerns & 35 & 9 & 18 & $0.003^{*}$ \\
\hline New research or first-in-human experimentation & 12 & 8 & 5 & 0.607 \\
\hline Long timeline to clinical implementation & 15 & 5 & 4 & $0.002^{*}$ \\
\hline Historical adverse events in gene transfer clinical trials & 8 & 0 & 11 & $0.006^{*}$ \\
\hline Eye health risk & 8 & 3 & 7 & 0.299 \\
\hline Unknown risk/Uncertain risk & 15 & 0 & 5 & $0.003^{*}$ \\
\hline Complexity of gene transfer & 4 & 6 & 0 & 0.143 \\
\hline Economic risk & 11 & 0 & 0 & $0.004^{*}$ \\
\hline Ethical challenges & 4 & 0 & 0 & 0.075 \\
\hline Social challenges & 0 & 1 & 0 & 1.000 \\
\hline Quality of life concerns arising from clinical trial participation & 4 & 0 & 0 & 0.165 \\
\hline Legal risk & 0 & 0 & 0 & 1.000 \\
\hline
\end{tabular}

${ }^{\mathrm{a} S t a t i s t i c a l l y ~ s i g n i f i c a n t ~ d i f f e r e n c e s ~}(p<0.05)$ are indicated by *.

genetic cause of retinopathies and were most inaccurate in their depiction of the purpose and methodology of gene transfer. Differences in coverage patterns were likely due to the number of articles in newspapers of varying quality per country (e.g., national versus local and broadsheet versus tabloid) and attention to local research. For example, Canadian articles reported more pre-clinical research, reflecting the state of gene transfer in Canada.

Recommendations to address these media challenges are many and include describing scientific roadblocks and the possibility of findings being invalidated by further studies [30]; encouraging reporters to consult

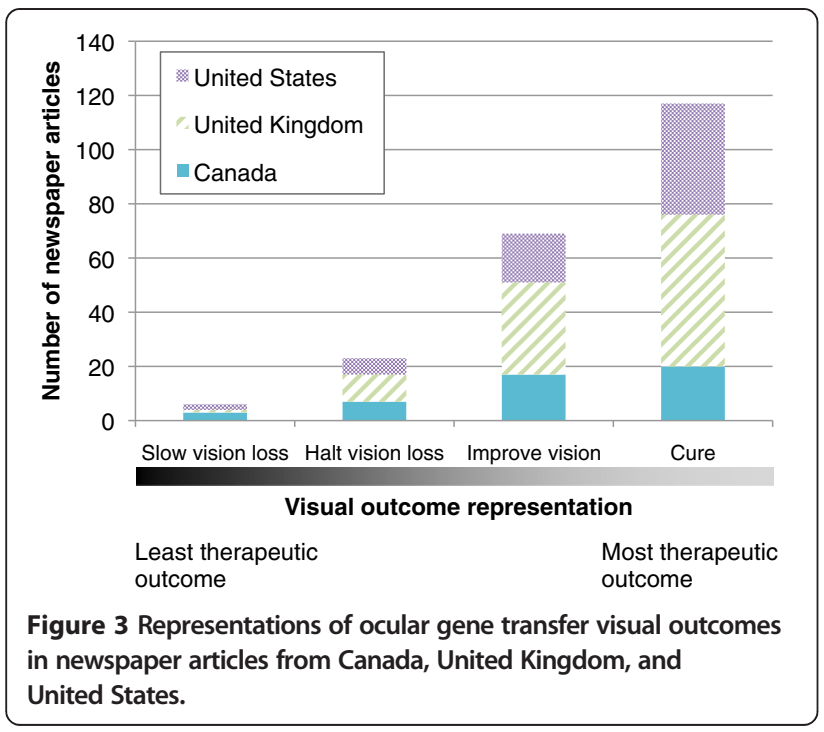

independent sources of information about the implications of scientific advances [41]; and encouraging researchers to disclose conflicts-of-interest to reporters $[21,22]$. Proposed educational strategies to promote balanced reporting include training researchers to "stick to the facts" when communicating with reporters; training graduate students-as future spokespeople-in effective science communication strategies [20]; inviting reporters to scientific conferences; and creating accessible materials to educate the news media about scientific advances [42].

Unfortunately, these recommendations do not adequately account for the nature of news media, which, as businesses, face their own pressures. Journalists produce copy within limited deadlines and compete fiercely for editorial and public attention. While increasing web content expands potential to provide further background material, print and television media still face space or time constraints. Our findings on frames and emphasis of benefits over risks highlight that ocular gene transfer is seen as a "good news" story for the visually impaired and their families. Our analysis confirms that decades of recommendations and initiatives to improve the tenor and content of science journalism have resulted in limited discernible improvement, at least, in the context of ocular gene transfer. As a result, recommendations may be more tractable at the level of clinical communications between clinicians and patient communities. Here, we first place our results in the context of other studies and then recommend the development of communication strategies between clinicians and their patients, especially potential clinical trial participants, that operate within the landscape of overly optimistic media coverage. 
Table 6 Illustrative timeline estimates for ocular gene transfer clinical trials or clinical application

\begin{tabular}{|c|c|c|c|}
\hline Timeline estimate & $\begin{array}{l}\text { Predicted year } \\
\text { for outcome }\end{array}$ & Outcome & Source \\
\hline $\begin{array}{l}\text { "Bennett, an associate professor of ophthalmology } \\
\text { at the University of Pennsylvania... said she hopes } \\
\text { initial experiments in people can begin within } \\
\text { about two years." }\end{array}$ & 2003 & $\begin{array}{l}\text { Leber congenital amaurosis clinical trials } \\
\text { began in 2007, with phase-l results published } \\
\text { in } 2008 \text { (Bainbridge et al., [6]; Hauswirth } \\
\text { et al., [7]; Maguire et al., [8]). }\end{array}$ & $\begin{array}{l}\text { Anonymous: Gene therapy restores } \\
\text { dogs' eyesight, may treat blind. } \\
\text { Houston Chronicle; 2001, April } 28 .\end{array}$ \\
\hline \multirow{2}{*}{$\begin{array}{l}\text { "Within five years [gene transfer] could be ready } \\
\text { for testing on people who suffer age-related } \\
\text { macular degeneration." }\end{array}$} & \multirow[t]{2}{*}{2013} & \multirow[t]{2}{*}{$\begin{array}{l}\text { Phase I clinical trials were initiated in } \\
2010 \text { (NCT01678872). }\end{array}$} & $\begin{array}{l}\text { Highfield R: Hope of genetic cure } \\
\text { for failing eyesight. }\end{array}$ \\
\hline & & & The Daily Telegraph; 2008, April 28. \\
\hline $\begin{array}{l}\text { "This [phase-I gene transfer clinical trial for Leber } \\
\text { congenital amaurosis] really paves the way for } \\
\text { developing a treatment for people who have so } \\
\text { far had no prospect of a cure," said Robin Ali, an } \\
\text { ophthalmologist at UCL... "Within two to three } \\
\text { years it might be approved for use in the clinic." }\end{array}$ & 2010-2011 & $\begin{array}{l}\text { Leber congenital amaurosis is currently } \\
\text { recruiting for a phase-III clinical trial } \\
\text { (NCT00999609). }\end{array}$ & $\begin{array}{l}\text { Sample I: Maze walk marks 'huge } \\
\text { advance' in gene therapy for blindness. } \\
\text { The Guardian; 2008, April } 28 .\end{array}$ \\
\hline $\begin{array}{l}\text { "[achromatopsia] treatment could be as little } \\
\text { as four or five years away." }\end{array}$ & 2016-2017 & To be determined. & $\begin{array}{l}\text { Hilpen K: The boy who sees in } \\
\text { black and white. The Daily } \\
\text { Express; 2012, March } 6 .\end{array}$ \\
\hline
\end{tabular}

\section{Frames, benefits, and therapeutic misconception}

Researchers from universities and research institutes were the dominant spokespeople, and clinical researchers, in particular, were represented as heroes [43]. The public places a high degree of trust in such researchers [44], and their statements lend credibility to media reports. Ransohoff \& Ransohoff characterize the relationship between media and researchers as one of "complicit collaboration" [39], both promoting promise as well as attracting funds and public support [45]. Indeed, researchers who perceive that media attention will promote their work are most often represented in the news media [46]. As such, researchers are compelled by careerist pressures and serve as partisan stakeholders in media communications [13].

Human-interest stories focused on patients and families $[47,48]$, which presented the narrative of gene transfer through a lens of hope, compassion, empowerment, and heroism [49]. Such narratives are a "powerful way of both universalizing and personalizing human experience" [50]. Emotive descriptions generate the most public conversation and reflection [47]; capture the attention of policy makers; and provide a platform for disease advocacy and funding opportunities $[48,51]$. Nevertheless they may mask the scientific information presented in media reports [47].

While newspaper articles, especially those with longer format, may have more than one frame, in our dataset, the dominant frame was a "celebration of progress", which was consistent with other novel medical biotechnologies $[19,32]$. This frame generates the social expectations necessary to sustain public support for gene transfer [40], but detracts from risks and reinforces optimistic messages of benefits [20]. Frames are most effective when they resonate with audiences on a psychological level [52]. As such, frames of progress may reinforce the hopes of patients and their families.
Often missing from the positive frames were explanations of research design [53] —including sample size and study phase-that conflated research with treatment. Conflicts-of-interest or funding sources were similarly omitted. Such omission diminishes transparency and the ability of the public to critically evaluate the stakes of interested and affected parties in the research effort $[28,31,53]$. Funding or other conflicts-of-interest should always be visible in media reports $[21,22]$, especially in consideration of the checkered history of gene transfer. An early gene transfer trial for ornithine transcarbamylase deficiency at the University of Pennsylvania, which resulted in the death of a young participant, is regarded as "the most famous conflict-of-interest case in medicine" [2]. It resulted in a loss of public trust [5], which is essential for the sustainable translation of this biotechnology [54].

Supporting the positive framing was an overemphasis on benefits at the expense of a discussion of risks $[28,31,53,55,56]$. Risks are notoriously difficult to explain to lay audiences, including journalists, because of inaccessibility of probabilistic information [57]. Ethical and social risks also go underreported [20,42,58], even though, one study of social media indicated public concern about these [59]. Most importantly, however, serious risks exist for clinical research participants in ocular as well as other gene transfer interventions. Oncogenic risks arise from insertional mutagenesis and a severe immune response to the viral vector has resulted in death [1]. Risks specific to ocular gene transfer include surgical complications, loss of an eye due to inflammation, loss of remaining vision, as well as the very low risk of brain toxicity due to viral vector integration into the optic nerve [6-8,33,60]. A discussion of risks emphasizes the early-stage, experimental nature of the technology, which has historically been associated with risk and uncertainty. 
As is common for novel biotechnologies, benefits were the focus of the articles [19,42,55,59]. Media emphasized direct visual benefits, giving patients and families hope for a similar outcome even though most reported studies were pre-clinical or phase I trials, focused on safety not efficacy. Additionally, media articles conflated goals of research and of clinical care: a phenomenon that is termed therapeutic misconception [61]. Therapeutic misonception is ethically problematic because an understanding of the goals of a clinical trial is necessary for autonomous decision-making and informed consent for research participants [62].

The extent to which media coverage contributes to therapeutic misconception is not known. However, one survey of prospective participants for a phase I oncology clinical trial found that exposure to media reports did not result in therapeutic misconception among patients [63]: $47 \%$ of patients who first heard about the trial from the news media correctly identified its purpose prior to informed consent compared to only $15 \%$ of patients who did not encounter media descriptions. Nevertheless, therapeutic benefit was the most prominent motivator for participation, meaning that therapeutic optimism can coexist with a correct understanding of the purpose of a phase I clinical trial [63].

More concerning is the news media focus on curative discourse-a phenomenon common in media coverage of prospective biotechnologies [49]. With respect to ocular gene transfer, however, the hope for a cure may be misplaced. Jacobson et al. [64] demonstrated that while vision loss can be halted and even improved by restoring function of dormant but otherwise viable photoreceptors, a cure is not theoretically afforded by gene transfer. This is because gene transfer is non-regenerative, and therefore cannot revive degenerated photoreceptors [64]. Recent evidence also suggests that despite visual improvement, retinal degeneration continues to progress in canine models and humans after LCA gene transfer [65], meaning that long-term efficacy may not be established through ocular gene transfer alone.

Media representations of a cure, while catchy, are inaccurate and misrepresent the theoretical promise of gene transfer research. They leave potential clinical trial participants vulnerable to therapeutic misestimation, whereby benefits are overestimated and risks underestimated [62]. While therapeutic misestimation may sometimes be ethically tolerable because an understanding of the exact probability of benefit is not necessary to make an autonomous decision about participation [62], curative perspectives present a misestimation of the magnitude of benefit rather than its probability. While it is impossible to convey exact probabilities for benefits in novel clinical trials, there is an ethical obligation to avoid raising patient hopes for benefits known to be theoretically infeasible.
Finally, the majority of articles failed to contextualize timelines for clinical application of ocular gene transfer. Media articles implied that therapeutic benefits were imminent, despite their early stages of development. Similarly, media portrayals of time estimates for gene discoveries for psychiatric condition and the availability of clinical services were largely unmet [58]. Such portrayals of present research outcomes may be ethically problematic for patients, as they may inflate expectations for a treatment in ongoing or future clinical trials and set patients up for disappointment [23].

In summary, newspaper communications about ocular gene transfer were replete with errors of omission and employed optimistic frames commonly used to generate social expectations about novel biotechnologies [40]. Benefits were over-represented and risks were often not discussed. Moreover, the focus on curative language within a therapeutic spectrum raises challenges for the ethical communication about ocular gene transfer in the context of recruiting clinical trials.

\section{Limitations}

This study only examined newspaper coverage and not Internet or television content, however, leading newspapers have an agenda setting role, serving as a platform for other media venues. With the exception of coding for curative visual benefits, this study did not assess media bias through "errors of commission" [20] as it did not compare the content of media coverage with that of scientific journal and clinical publications. Despite this shortcoming, this study explored the lack of balance in media reporting through the more common forms of omission and framing biases $[28,31,32]$. Finally, the study did not examine the impact of media coverage directly on potential participants in recruiting clinical trials and their families. While we interviewed patients about the prospect of an ocular gene transfer clinical trial for choroideremia and their responses informed the coding frame, the proposed trial was not yet recruiting participants.

\section{Conclusions}

This study shows little improvement in science media communication in the past decade, despite initiatives to improve journalism on novel health technologies $[20,28,30,31,41,42,47]$. Media reports continue to be overly optimistic and framed as human-interest stories, whether from the perspective of the heroic researcher or hopeful patient. We therefore reiterate that clinicians and researchers, in their encounters with the news media, should be factual, balanced in addressing both risks and benefits, disclose funding sources and conflictsof-interest, provide realistic timelines, and discourage curative speculation when research is either in early 
stages or when a cure is not theoretically possible. As a further incentive for moderated media communications, we support Kimmelman's [66] recommendation that institutional review boards require investigators of clinical trials to submit a portfolio of their press releases as a component of ethics review [66].

At a more practical level, however, and one that is directly in the control of researchers/clinicians, the onus must be on these stakeholders to address the backdrop of media coverage in the context of ongoing clinical care and clinical trial enrolment. In particular, researchers and clinicians must distinguish between the goals of research, of the phases of clinical investigation, and treatment. Additionally, clinical communicators must counter media messaging, emphasizing to their patients that a cure will not be afforded through gene transfer alone. Taking media communications into account when discussing the potential of ocular gene transfer clinical trials will promote 'informed hope' among patients in the context of clinical care [67], informed consent among research participants in the context of recruiting trials, and facilitate the ethical translation of this biotechnology as it moves towards clinical application.

\section{Abbreviation \\ LCA: Leber congenital amaurosis.}

\section{Competing interests}

The authors declare that they have no competing interests.

\section{Authors' contributions}

SB and TB conceptualized the research questions and study design. SB collected, coded, supervised coding done by a research assistant, and carried out statistical analyses. SB and TB drafted, edited, and approved the final manuscript.

\section{Authors' information}

Ms. Shelly Benjaminy has a BSc in molecular genetics and an MSc in health policy from the University of Alberta. Her research explores multi-stakeholder priorities for the translation of novel biotechnologies. Dr. Tania Bubela has a PhD from the University of Sydney in biology and a JD from the University of Alberta. She researches in the field of health law and policy as an Associate Professor, School of Public Health, University of Alberta.

\section{Acknowledgements \\ We thank Mackenzie Martin for assistance in coding, Dale Storie for help in developing search algorithms, Professor Gian Jhangri for statistical advice, and Dr. Ian MacDonald, Dr. Cindy Jardine, and Professor Timothy Caulfield for comments on a previous version of this manuscript. Finally, we would also like to thank the research participants from the choroideremia community who shared their perspectives with us to inform the coding frame of this analysis. This study was supported by the Canadian Institutes of Health Research, Foundation Fighting Blindness Canada, and the Choroideremia Research Foundation Canada Inc. The funders had no role in study design, data collection and analysis, decision to publish, or preparation of the manuscript.}

Received: 22 May 2013 Accepted: 10 July 2014

Published: 16 July 2014

\section{References}

1. Wilson JM: Lessons learned from the gene therapy trial for ornithine transcarbamylase deficiency. Mol Genet Metab 2009, 96(4):151-157.

2. Wilson RF: The death of Jesse Gelsinger: new evidence of the influence of money and prestige in human research. Am J Law Med 2010, 36(2-3):295-325
3. Wolf SM, Gupta R, Kohlhepp P: Gene therapy oversight: lessons for nanobiotechnology. J Law Med Ethics 2009, 37(01):659-684.

4. Smith L, Byers JF: Gene transfer in the post-Gelsinger era. JONAS Healthc Law Ethics Regul 2002, 4(4):104-110.

5. Yarborough M, Sharp RR: Public trust and research a decade later: what have we learned since Jesse Gelsinger's death? Mol Genet Metab 2009, 97(1):4-5.

6. Bainbridge JWB, Smith AJ, Barker SS, Robbie S, Henderson R, Balaggan K, Viswanathan A, Holder GE, Stockman A, Bhattacharya SS, Thrasher AJ, Fitzke FW, Carter BJ, Rubin GS, Moore AT, Ali RR: Effect of gene therapy on visual function in Leber's congenital amaurosis. N Engl J Med 2008, 358(21):2231-2239.

7. Hauswirth WW, Aleman TS, Kaushal S, Cideciyan AV, Schwartz SB, Wang L, Conlon TJ, Boye SL, Flotte TR, Byrne BJ, Jacobson SG: Treatment of Leber congenital amaurosis due to RPE65 mutations by ocular subretinal injection of adeno-associated virus gene vector: short-term results of a phase I trial. Hum Gene Ther 2008, 19(10):979-990.

8. Maguire AM, Simonelli F, Pierce EA, Pugh EN, Mingozzi F, Bennicelli J, Banfi S, Marshall KA, Testa F, Surace EM, Rossi S, Lyubarsky A, Arruda VR, Konkle B, Stone E, Sun J, Jacobs J, Dell'Osso L, Hertle R, Ma J, Redmond TM, Zhu X, Hauck B, Zelenaia O, Shindler KS, Maguire MG, Wright JF, Volpe NJ, McDonnell JW, Auricchio A, et al: Safety and efficacy of gene transfer for Leber's congenital amaurosis. N Engl J Med 2008, 358(21):2240-2248.

9. Simonelli F, Maguire AM, Testa F, Pierce EA, Mingozzi F, Bennicelli JL, Rossi S, Marshall K, Banfi S, Surace EM, Sun J, Redmond TM, Zhu X, Shindler KS, Ying G, Ziviello C, Acerral C, Wright JF, McDonnell JW, High KA, Bennett J, Auricchio A: Gene therapy for Leber's congenital amaurosis is safe and effective through 1.5 years after vector administration. Mol Ther 2010, 18(3):643-650.

10. Smith AJ, Bainbridge JW, Ali RR: Prospects for retinal gene replacement therapy. Trends Genet 2009, 25(4):156-165.

11. Kaplan J: Leber congenital amaurosis: from darkness to spotlight. Ophthalmic Genet 2008, 29(3):92-98.

12. Heon E: My child has Leber congenital amaurosis: why is he/she not eligible for gene therapy trials? J AAPOS 2009, 13(6):533-534.

13. Caulfield T, Condit C: Science and the sources of hype. Public Health Genomics 2012, 15(3-4):209-217.

14. Holtzman NA: Are genetic tests adequately regulated? Science 1999, 286(5439):409.

15. Gamson WA, Modigliani A: Media discourse and public opinion on nuclear power: a constructionist approach. Am J of Sociol 1989, 95(1):1-37.

16. Nisbet M, Goidel R: Understanding citizen perceptions of science controversy: bridging the ethnographic survey research divide. Public Underst Sci 2007, 16(4):421-440.

17. Nisbet MC, Brossard D, Kroepsch A: Framing science the stem cell controversy in an age of press/politics. IJPP 2003, 8(2):36-70.

18. Caulfield T, Zarzeczny A, McCormick J, Bubela T, Critchley C, Einsiedel E, Galipeau J, Harmon S, Huynh M, Hyun I, Illes J, Isasi R, Joly Y, Laurie G, Lomax G, Longstaff H, Mcdonald M, Murdoch C, Ogbogu U, Owen-Smith J, Pattinson S, Premji S, von Tigerstrom B, Winickoff DE: The stem cell research environment: a patchwork of patchworks. Stem Cell Rev 2009, 5(2):82-88.

19. Jensen E: Scientific sensationalism in American and British press coverage of therapeutic cloning. J Mass Commun Q 2012, 89(1):40-54.

20. Bubela T, Hyde-Lay R, Lane S, Ogbogu U, Ouellette C, Nisbet MC, Borchelt R, Brunger F, Critchley C, Einsiedel E, Geller G, Gupta A, Hampel J, Hyde-Lay R, Jandciu EW, Jones SA, Kolopack P, Lane S, Lougheed T, Nerlich B, Ogbogu U, O'Riordan K, Ouellette C, Spear M, Strauss S, Thavaratnam T, Willemse L, Caulfield T: Science communication reconsidered. Nat Biotechnol 2009, 27(6):514-518.

21. Myers EF, Parrott JS, Cummins DS, Splett P: Funding source and research report quality in nutrition practice-related research. PLoS One 2011, 6(12):e28437.

22. Cook DM, Boyd EA, Grossmann C, Bero LA: Journalists and conflicts of interest in science: beliefs and practices. Ethics Sci Environ Polit 2009, 9:33-40.

23. Petersen A: The ethics of expectations: biobanks and the promise of personalised medicine. Monash Bioeth Rev 2009, 28(1):1-12.

24. Daugherty CK, Banik DM, Janish L, Ratain MJ: Quantitative analysis of ethical issues in phase I trials: a survey interview study of 144 advanced cancer patients. IRB 2000, 22(3):6-14.

25. Pentz RD, Harvey RD, Owonikoko T, Khuri FR, White M, Farmer ZL, Liu Y, Lewis C, Dashevskaya O: Therapeutic misconception, misestimation, and 
optimism in participants enrolled in phase 1 trials. Cancer 2012, 118(18):4571-4578.

26. Alliance for audited media. http://www.auditedmedia.com.

27. National Institutes of Health: ClinicalTrials.gov. http://www.clinicaltrials.gov/ ct2/results/map?term=gene+therapy.

28. Bubela TM, Caulfield TA: Do the print media "hype" genetic research? A comparison of newspaper stories and peer-reviewed research papers. CMAJ 2004, 170(9):1399-1407.

29. Bubela T, Boon H, Caulfield T: Herbal remedy clinical trials in the media: a comparison with the coverage of conventional pharmaceuticals. BMC Med 2008, 6(1):35.

30. Condit $\mathrm{CM}$ : How geneticists can help reporters to get their story right. Nat Rev Genet 2007, 8(10):815-820.

31. Holtzman NA, Bernhardt BA, Mountcastle-Shah E, Rodgers JE, Tambor E, Geller G: The quality of media reports on discoveries related to human genetic diseases. Community Genet 2005, 8(3):133-144.

32. Nisbet MC: Framing Science: A New Paradigm in Public Engagement. In Understanding Science: New Agendas in Science Communication. Edited by Kahlor L, Stout P. New York: Taylor and Francis; 2009:40-67.

33. Benjaminy S, MacDonald I, Bubela T: "Is a cure in my sight?": Multistakeholder perspectives on phase I choroideremia gene transfer clinical trials. Genet Med 2014, 16(5):379-385.

34. Neuendorf KA: The Content Analysis Guidebook. Thousand Oaks, California: Sage Publications; 2002.

35. Campbell J: Science Gives Blind Dogs Sight: 'First Fruit of Genetic revolution' Raises Hope for Fighting Other Genetic Diseases. Ottawa: The Ottawa Citizen; 2001.

36. Sample I: Gene Therapy Aimed at Restoring Sight for 30,000 People. London: The Guardian; 2007.

37. Mick H: Gene Therapy Shines Light on Blindness. Toronto: The Globe and Mail; 2008.

38. Willey J: Blind Will 'see' Within a few Days of Gene Therapy. London: The Daily Express; 2008

39. Ransohoff DF, Ransohoff RM: Sensationalism in the media: when scientists and journalists may be complicit collaborators. Eff Clin Pract 2001, 4(4):185-188.

40. Hedgecoe A: The Politics of Personalised Medicine: Pharmacogenetics in the Clinic. Cambridge: Cambridge University Press; 2004.

41. Brechman JM, Lee CJ, Cappella JN: Distorting genetic research about cancer: from bench science to press release to published news. J Commun 2011, 61(3):496-513

42. Ogbogu U, Du L, Rachul C, Bélanger L, Caulfield T: Chinese newspaper coverage of (unproven) stem cell therapies and their providers. Stem Cell Rev 2013, 9(2):1-8.

43. Horst M: Public expectations of gene therapy scientific futures and their performative effects on scientific citizenship. Sci Technol Hum Values 2007, 32(2):150-171.

44. Critchley CR: Public opinion and trust in scientists: the role of the research context, and the perceived motivation of stem cell researchers. Public Underst Sci 2008, 17(3):309-327.

45. Kimmelman J: Gene Transfer and the Ethics of First-in-Human Research: Lost in Translation. Cambridge: Cambridge University Press; 2010

46. Tsfati Y, Cohen J, Gunther AC: The influence of presumed media influence on news about science and scientists. Sci Commun 2011, 33(2):143-166.

47. Henderson L, Kitzinger J: The human drama of genetics: 'hard' and 'soft' media representations of inherited breast cancer. Sociol Health IIIn 1999, 21(5):560-578

48. McKeever BW: News framing of autism understanding media advocacy and the combating Autism Act. Sci Commun 2013, 35(2):213-240.

49. Kitzinger J, Williams C: Forecasting science futures: legitimising hope and calming fears in the embryo stem cell debate. Soc Sci Med 2005, 61(3):731-740.

50. Petersen A: Biofantasies: genetics and medicine in the print news media. Soc Sci Med 2001, 52(8):1255-1268.

51. Jensen E: Mediating subpolitics in US and UK science news. Public Underst Sci 2012, 21(1):68-83.

52. Nisbet MC, Scheufele DA: What's next for science communication? Promising directions and lingering distractions. Am J Bot 2009, 96(10):1767-1778.

53. Racine $\mathrm{E}$, Waldman S, Rosenberg J, Illes J: Contemporary neuroscience in the media. Soc Sci Med 2010, 71(4):725-733
54. Critchley CR, Nicol D: Understanding the impact of commercialization on public support for scientific research: is it about the funding source or the organization conducting the research? Public Underst Sci 2011, 20(3):347-366.

55. Vicsek L: Costs and benefits of stem cell research and treatment: media presentation and audience understanding in Hungary. Sci Commun 2011, 33(3):309-340

56. Caulfield T, McGuire AL: Direct-to-consumer genetic testing: perceptions, problems, and policy responses. Annu Rev Med 2012, 63:23-33.

57. Condit C: What is 'public opinion' about genetics? Nat Rev Genet 2001, 2(10):811-815

58. Wilde A, Bonfiglioli C, Meiser B, Mitchell PB, Schofield PR: Portrayal of psychiatric genetics in Australian print news media, 1996-2009. Med J Aust 2011, 195(7):401-404.

59. Robillard JM, Whiteley L, Johnson TW, Lim J, Wasserman WW, Illes J: Utilizing social media to study information-seeking and ethical issues in gene therapy. J Med Internet Res 2013, 15(3):e44.

60. Acland GM, Aguirre GD, Ray J, Zhang Q, Aleman TS, Cideciyan AV, Pearce-Kelling SE, Anand V, Zeng Y, Maguire AM, Jacobson SG, Hauswirth WW, Bennett J: Gene therapy restores vision in a canine model of childhood blindness. Nat Genet 2001, 28(1):92-95.

61. Appelbaum PS, Roth LH, Lidz C: The therapeutic misconception: informed consent in psychiatric research. Int J Law Psychiatry 1982, 5(3-4):3-4.

62. Horng S, Grady C: Misunderstanding in clinical research: distinguishing therapeutic misconception, therapeutic misestimation, and therapeutic optimism. IRB 2003, 25(1):11-16.

63. Pentz RD, Flamm AL, Sugarman J, Cohen MZ, Ayers GD, Herbst RS, Abbruzzese $J$ : Study of the media's potential influence on prospective research participants' understanding of and motivations for participation in a high-profile phase I trial. J Clin Oncol 2002, 20(18):3785-3791.

64. Jacobson SG, Aleman TS, Cideciyan AV, Sumaroka A, Schwartz SB, Windsor EAM, Traboulsi El, Heon E, Pittler SJ, Milam AH, Maguire AM, Placzewski K, Stone EM, Bennett J: Identifying photoreceptors in blind eyes caused by RPE65 mutations: prerequisite for human gene therapy success. Proc Natl Acad Sci U S A 2005, 102(17):6177-6182.

65. Cideciyan AV, Jacobson SG, Beltran WA, Sumaroka A, Swider M, Iwabe S, Roman AJ, Olivares MB, Schwartz SB, Komáromy AM, Hauswirth WW Aguirre GD: Human retinal gene therapy for Leber congenital amaurosis shows advancing retinal degeneration despite enduring visual improvement. Proc Natl Acad Sci U S A 2013, 110(6):E517-E525.

66. Kimmelman J: Ethics of cancer gene transfer clinical research. Methods $\mathrm{Mol}$ Biol 2009, 542:423-445.

67. Reimer J, Borgelt E, Illes J: In pursuit of "informed hope" in the stem cell discourse. Am J Bioeth 2010, 10(5):31-32.

doi:10.1186/1472-6939-15-58

Cite this article as: Benjaminy and Bubela: Ocular gene transfer in the spotlight: implications of newspaper content for clinical communications. BMC Medical Ethics 2014 15:58.

\section{Submit your next manuscript to BioMed Central and take full advantage of:}

- Convenient online submission

- Thorough peer review

- No space constraints or color figure charges

- Immediate publication on acceptance

- Inclusion in PubMed, CAS, Scopus and Google Scholar

- Research which is freely available for redistribution 